\title{
A müvi abortusz a férfi partner szemszögéből
}

\author{
Nagy Beáta Magda ${ }^{1,2}$ - Rigó Adrien dr. ${ }^{1}$ \\ ${ }^{1}$ Eötvös Loránd Tudományegyetem, Bölcsészet- és Társadalomtudományi Kar, Pszichológiai Intézet, Budapest \\ ${ }^{2}$ Eötvös Loránd Tudományegyetem, Pedagógiai és Pszichológiai Kar, Pszichológiai Doktori Iskola, Budapest
}

\begin{abstract}
A múvi abortusz olyan esemény, amelyet elsődlegesen a nők nézőpontjából vizsgálnak a kutatások, akár a döntés oka, akár annak következménye a kérdés. Pedig minden egyes terhességmegszakítás (éppúgy, ahogy a várandósság létrejötte) érint egy férfit is, ezért fontos volna, hogy minél több ismeretünk legyen a férfi partnerek múvi abortusszal kapcsolatos megéléséről, saját igényeiről és szükségleteiről. Összefoglalónkban az abortuszellátás gyakorlata szempontjából vizsgáljuk a férfi partnerek helyzetét és szerepét. A rendelkezésre álló kutatási eredmények szerint a férfiak bevonása az abortuszellátásba részben a saját érzelmi egyensúlyuk, részben pedig a nő alkalmazkodásának elősegítése miatt fontos. A hangsúlyosabb szerepvállalás jelentheti egyrészt a részvételt az abortusz előtti tanácsadáson, a nő elkísérését a terhességmegszakításra, a férfi partner jelenlétét az abortusz megtörténtekor, illetve az abortusz utáni gondozásban való részvételt. A kutatások eredményei szerint a fentiek mindegyike pozitív kapcsolatban áll a nő kedvező abortusztapasztalataival (amennyiben a nő a férfi bevonását támogatja) és így gyorsabb felépülésével. A férfi partnerek fokozottabb jelenléte az abortuszellátás folyamatában a szolgáltatók oldaláról lehetôséget ad a megfelelő, saját igényekhez igazított tájékoztatásra is (magáról a beavatkozásról, a lehetséges következményekről vagy a fogamzásgátlás lehetőségeiről stb.). Az érintett férfiak bevonása az ellátás folyamatába, valamint az igényeikhez, elvárásaikhoz igazított információátadási, tanácsadási és intervenciós gyakorlatok alkalmazása támogatja a párok közös és informált döntését, a fogantatásért, illetve fogamzásgátlásért vállalt közös felelősségvállalást, és mindezen keresztül segítheti a múvi terhességmegszakítások számának csökkenését is.
\end{abstract}

Orv Hetil. 2019; 160(18): 694-699.

Kulcsszavak: múvi abortusz, férfiak, abortuszellátás

\section{Artificial abortus from the male partner's perspective}

Induced abortion is an intervention that scientific research primarily addresses from the concerned women's point of view in terms of either the causes or the consequences of the abortion decision. Nevertheless, each case of abortion involves a man as much as a woman (in the same vein as conception), which calls for the better knowledge of male partners' needs, expectations and experiences related to induced abortion. The present summary addresses male partners' status and importance in abortion care in a practical approach based on professional considerations. Available empirical findings suggest that male partners' involvement in abortion care has importance both in protecting men's emotional balance and in providing support for women in adapting to the abortion process. Male partners' deeper involvement possibly includes roles such as seeing the female partner to the intervention, participation in preabortion counselling, presence during the intervention, and participation in post-abortion care. Related findings show that all of these forms of support are related to women's positive abortion-related experiences and thus to their better recovery (provided that the female partner expresses a need for her male partner's personal support). Furthermore, male partners' involvement in abortion care enables health care providers to tailor counselling (information on the intervention, on possible consequences, on contraceptive methods etc.) to men's specific needs. These practices facilitate partners' joint and informed decision making, joint responsibility for conception or contraception, and eventually contribute to reducing the incidence of induced abortion.

Keywords: induced abortion, men, abortion care

Nagy BM, Rigó A. [Artificial abortus from the male partner's perspective]. Orv Hetil. 2019; 160(18): 694-699.

(Beérkezett: 2018. november 6.; elfogadva: 2018. december 28.) 
A múvi abortuszok száma Magyarországon közel két évtizede csökkenő tendenciát mutat. 2017-ben a megszakíttatott várandósságok száma 28,5 ezer volt, ami az előző évi adatokhoz képest 6,4 százalékos csökkenést, az 1990-es évek mutatóihoz képest kevesebb mint egyharmados gyakoriságot jelent, a befejezett terhességek számához viszonyítva azonban még mindig nagyjából minden három élveszületésre jut egy múvi abortusz [1]. A legális abortuszok számát az ismert terhességekhez viszonyítva a 2015-ös adatok alapján hazánk világviszonylatban a tizenkilencedik, az Európai Unió tagállamai közül a negyedik helyen áll [2].

Hazánkban az érvényes törvényi szabályozás szerint (1992. évi LXXIX. törvény) a válsághelyzetre hivatkozva várandósságuk mûvi megszakítását igénylő nők kötelesek két alkalommal tanácsadáson részt venni, melyet a Családvédelmi Szolgálatok szakirányú képzettséggel rendelkező védőnői végeznek. A tanácsadás célja részben az informálás (például a gyermek vállalása esetén elérhető támogatási formákról, segítséget biztosító szervezetekről, az örökbe adás lehetőségeiről, a terhességmegszakítás veszélyeiről stb.), részben pedig a válsághelyzet enyhítése és a döntés támogatása, a magzati élet védelmének irányultságával. Mindkét alkalommal van mód arra, hogy a tanácsadáson a férfi partner is részt vegyen, ám erre a gyakorlatban viszonylag ritkán kerül sor: családvédelmi tanácsadást végző védőnők elmondása szerint (személyes kommunikáció, 2018. 10. 12.) tíz nőből egy-kettő az, akinek a partnere is részt vesz a tanácsadáson. Így viszont a férfiak elesnek a személyes, közvetlen tájékoztatástól és hiteles információktól, valamint a lehetőségtől is, hogy saját kérdéseiket megfogalmazzák, és azokra választ kapjanak. Másrészt az ellátók oldaláról is elveszik az az esély, hogy a terhességmegszakításban érintett férfiakat közvetlenül elérjék, miközben a férfiak a döntés fontos szereplői, így megfelelő informáltságuk kiemelkedően fontos volna.

Az idevonatkozó tudományos kutatások eredményei szerint a párok többsége (82-85\%) közösen hozza meg az abortuszra vonatkozó döntést; a házasságban élőknél, illetve a két évnél hosszabb ideje múködő kapcsolatokban az arány még ennél is magasabb [3-5]. A nemzetközi ajánlások hangsúlyozzák annak jelentőségét, hogy a döntés informált legyen $[6,7]$, ez azonban nemcsak a nő, hanem az érintett férfi oldaláról is lényeges. Feltehető, hogy csak az a partner tud kielégítő instrumentális és információs támogatást nyújtani a nőnek, aki maga is megfelelően tájékozott, márpedig az olyan praktikus teendők felvállalása, mint például a terhességmegszakítás költségeinek rendezése vagy időpont intézése, nagy jelentőséggel bír a nőre háruló pszichés terhek csökkentése szempontjából. Az észlelt érzelmi támasz emellett segít a helyzettel járó distressz mérséklésében, támogatja a hatékony megküzdést, és pozitívan hat az abortusz utáni időszakban a nő mentális egészségére is $[8,9]$. A férfi partner támogató hozzáállása lerövidíti a döntés meghozatalához szükséges időt, míg az egyet nem értés és/vagy a támogatás hiánya az abortusz kérvényezésének (és így végrehajtásának) késedelmével jár együtt, ami pedig a fizikai és pszichés komplikációk megjelenésének nagyobb valószínúségét idézi elő [10-12]. Annak, hogy a nók mennyire tudnak érzelmileg alkalmazkodni döntésükhöz (akár elvetetik a magzatukat, akár nem), fontos prediktora az, hogy mennyire érzik biztosnak magukat a döntésükben. A partnerek biztossága/bizonytalansága azonban egymással is összefügg: minél bizonytalanabb egy férfi a döntésben, annál bizonytalanabb a nő is $(r=$ $0,42)$, fóként együtt élő párok esetén $(\mathrm{r}=0,49)$ [13]. E bizonytalanság természetesen az információk hiányából vagy téves voltából is fakadhat [14] - ezért is volna fontos a férfi partnereket (is) megbízható, tudományosan alátámasztott információkkal ellátni.

A terhesség megszakítására irányuló informált és közös döntés támogatásában fontos szerep juthat az abortuszellátás intézményrendszerének, amennyiben az a férfi partnert is képes elérni és az ellátás folyamatába bevonni. Wallerstein már 1972-ben, egy észak-amerikai nők körében végzett vizsgálat során rögzítette: a terhességmegszakítás után a férfiak számára is lehetővé kell tenni a professzionális támogatás elérhetőségét. Az 1994-ben megrendezett Kairói Népesedési Világkonferencia (International Conference on Population and Development) pedig a férfiak megosztott felelösségének hangsúlyozása mellett sürgette a célzottan a férfiak számára kialakított reprodukciós egészségügyi szolgáltatások létrejöttét $[15,16]$.

Az alábbiakban bemutatásra kerülő tudományos kutatási eredmények döntően két kérdésre vonatkoznak: egyrészt azt vizsgálják, hogy milyen lehetőségek vannak a férfi partnerek bevonására az abortuszellátás folyamatába, másrészt hogy az érintett férfiak aktívabb szerepvállalása milyen hatást gyakorol a beavatkozás pszichés következményeire. A témában végzett vizsgálatok száma relatíve kicsi (főként az érintett nőket felmérő kutatásokhoz képest), ráadásul többnyire statisztikailag alacsony magyarázóértékkel bírnak; eredményeik bemutatását azért tartjuk mégis hasznosnak, mert a kapott információk mellett egyben jól reprezentálják a téma kutatásának nehézségeit és buktatóit is.

\section{A férfi partner részvétele az abortuszellátás folyamatában}

Altshuler és mtsai 2016-ban szisztematikus áttekintést készítettek a férfiaknak az abortuszellátásba való bevonására vonatkozó tudományos eredményekből, melynek során 15, 1985 és 2012 között publikált tanulmányt elemeztek. A szerzők összegzése szerint, bár a bizonyítékok nem magas szintúek, az eredmények arra utalnak, hogy a férfi partnerek részvétele az abortuszellátásban (a nő támogató beleegyezésével, szem előtt tartva a biztonságos ellátás szükségességét, például bántalmazó partner esetén) pozitív kapcsolatban áll a nők abortusztapasztalatával; negatív irányú összefüggést egy kutatásban sem találtak [16]. 
$\mathrm{Az}$ áttekintésben szereplő tanulmányokban a férfi partner bevonásának négy típusa volt elkülöníthető.

\section{Részvétel az abortusz elótti tanácsadáson}

Arra a kérdésre, hogy milyen hatással jár a férfi partner bevonása a tanácsadásba, az elemzett idôszakban csak egy kutatás irányult [17]. A vizsgálat során magáról az abortuszról, a beavatkozás utáni fogamzásgátlási lehetőségekról és egyéb, a pár által felvetett témákról szóló tanácsadáson vettek részt a párok. A tanácsadást követően a nók érzelmileg erősebben támogatottnak érezték magukat, megnyugtatónak tartották partnerük jelenlétét, úgy érezték, a hallott információk alapján partnerük jobban megérti, min mennek keresztül, és könnyebben meg tudták osztani partnerükkel a döntést.

\section{A nö elkisérése a terhességmegszakitásra}

Néhány vizsgálat arra irányult, hogy ha a férfi partner elkíséri a nő́t a beavatkozásra (vagyis jelen van az egészségügyi intézményben, ahol az abortusz történik), az hat-e a nő megküzdésére a beavatkozás után. A kutatások eredményei nem egyértelmúek, jelezve, hogy számos változó befolyásolhatja az abortusz utáni pszichés alkalmazkodást. Major és mtsai [18] szerint azok a nők, akiket partnerük elkísért, intenzívebb depressziós tüneteket mutattak, és több fizikai tünetről számoltak be a beavatkozás után fél órával, mint az egyedül lévő nők, de a háromhetes utánkövetésnél nem találtak szignifikáns különbséget a két csoport között. A szerzők azonban felhívják a figyelmet arra, hogy a két csoport (egyedül, illetve partnerrel érkezők) között az abortusztól függetlenül is voltak különbségek, és az eredmények eltérését ezek is okozhatták: azok a nők, akik partnerük kíséretében jelentkeztek be, jellemzően fiatalabbak voltak, és rosszabb megküzdési stratégiákkal rendelkeztek, mint a beavatkozásra egyedül érkezók. A közvetítő változók szerepét támasztja alá Major és kutatócsoportjának későbbi vizsgálata is, amelyben a társas támogatás és a jobb alkalmazkodás között az énhatékonyság mediáló szerepét igazolták [19]. Cozzarelli és mtsai [20] nem találtak összefüggést a férfi partner (várótermi) jelenléte és a nő posztabortusz depressziós tüneteinek mértéke között, de ez a vizsgálat is a distressz mértéke és az énhatékonyság közötti negatív irányú összefüggést bizonyította. A férfi partner által elkísért nők nagyobb fokú elköteleződést mutattak a párkapcsolatuk irányába, és társukat támogatóbbnak értékelték a várandósság óta eltelt időszak megélése, a közös döntés és a jövőbeli megbízhatóság vonatkozásában egyaránt.

Az, hogy a férfi elkíséri-e a nôt a terhességet megszakító beavatkozásra, befolyással bír a biztonságos abortuszhoz való hozzáférésre is, főként azokban a kultúrákban, ahol a házasságon kívüli szexuális aktivitás tabu. Ezekben a helyzetekben könnyebben jut a nő megfelelő ellátáshoz, ha partnere kíséri [16].

\section{Jelenlét az abortusz megtörténtekor}

Ezek a kutatások gyógyszeres és mútéti abortuszok esetén vizsgálták a férfi partner jelenlétét a beavatkozás alatt (abban a fizikai térben, ahol az abortusz konkrétan történik, a kórházban vagy otthon), illetve abban az időszakban, amelyben a nő gyógyszerhatás alatt áll.

A mútéti abortuszoknál a támogató partner jelenléte vagy annak lehetősége az ellátással való magasabb elégedettséggel jár együtt $[21,22]$, míg a gyógyszeres terhességmegszakításoknál az elégedettséget nem, de az eljárás elfogadottságát (mennyire ajánlaná a nő ezt a lehetőséget másoknak, illetve mennyiben választaná, ha újból szüksége volna rá) pozitívan befolyásolta a férfi partner jelenléte $[23,24]$. Mindez azért is fontos, mert összefüggés mutatható ki a nőknél az elláással való elégedettség és a későbbi pszichés állapot (elsősorban a poszttraumás stressz tüneteinek megjelenése) között [25]. A partner jelenlétét a nők érzelmileg fontosnak és segítőnek érezték, de az a fizikai tünetekre (fájdalom mértéke) nem volt hatással [26]. Kiemelten lényeges a társ támogatása az otthon végzett gyógyszeres abortuszoknál, érzelmi és praktikus szinten egyaránt, sốt a partner jelenlétének lehetősége e módszer választásának egyik fó oka [27].

\section{Részvétel az abortusz utáni gondozásban}

A férfi partner ottléte a beavatkozás után részben a társas támogatás, részben a nők szorongásának csökkentése miatt lényeges. Az utóbbi szempontjából a partner szerepe kitüntetett jelentőségư: a múvi abortusz után a nők pszichológiai alkalmazkodásának mutatói szignifikáns együtt járást mutatnak a partnertől kapott támogatás mértékével, de a szülői és a baráti támogatással nem [28, 29]. Az érintett nők és kíséróik többsége is hasznosnak itéli meg a férfi partner jelenlétét a regenerálódás időszakában [30].

Az, hogy a férfiak számára kialakított, abortusz utáni tanácsadás javítja-e a férfi által nyújtott támogatás minőségét, és segíti-e a nő felépülését, erős kulturális befolyás alatt áll. Egy olyan társadalomban, amelyben a férfiak részérôl az (érzelmi vagy instrumentális) támogatás nem bevett gyakorlat (például Egyiptom), azon önmagában a tanácsadás nem fog változtatni [31].

Amint látható, a szisztematikus áttekintésben szereplő minden egyes vizsgálat a férfiak bevonásának nókre gyakorolt hatásával foglalkozott, miközben a férfiaknak saját igényeik és szükségleteik is lehetnek az abortuszellátás során, amelyek egyrészt a megfeleló információkkal való ellátásra, másrészt az érzelmi támogatásra irányulnak.

\section{A férfiak szükségletei és igényei az abortuszellátás során}

Bár a szakirodalmi adatok erre vonatkozóan hiányosak, néhány kutatás alapján feltételezhető, hogy az abortuszellátásban részt vevő férfiak számára maga a helyzet (te- 
hát nem a terhesség megszakítására irányuló döntés, hanem például a nő fizikai fájdalmának látványa) önmagában is fokozott distresszt keltő élmény [32]. Ehhez járulnak hozzá azok a félelmek, amelyek az abortusznak a párkapcsolatra gyakorolt negatív hatására vagy az azt kísérő fájdalomra vonatkoznak. Nem véletlen, hogy kutatási eredmények szerint a beavatkozás előtt a férfiak 39,6\%-a tartozott a magas distresszértékeket mutató csoportba (ami szignifikánsan több az illesztett kontrollcsoporthoz képest), a háromhetes utánkövetésnél pedig 30,9\% (nem szignifikáns eltérés a kontrollcsoporthoz képest) [33]. A mütét közben a férfiak többnyire egyedül ülnek a váróban - a mellőzöttség és elszigeteltség érzése szintén a negatív érzelmi állapotok facilitálója lehet [34].

Részben a fentiek indokolhatják azt, hogy a terhességmegszakításban részes férfi partnerek jelentős része igényelné az abortusz előtti tanácsadáson való részvételt. Egy amerikai férfiakból álló mintán $(\mathrm{n}=905)$ végzett vizsgálatban a megkérdezettek 38\%-a az egyéni, míg 55\%-uk a partnerrel közös tanácsadás iránt érdeklődött, míg egy kisebb mintán $(\mathrm{n}=113)$ végzett kanadai vizsgálatban a férfiak harmada $(30,4 \%)$ fejezte ki igényét a tanácsadás valamely formája iránt $[33,35] .{ }^{1}$ Már egy korai vizsgálat eredményei is arra mutattak, hogy csökken a helyzethez kötődő szorongás szintje azoknál a férfiaknál, akik a partnerükkel együtt csoportos tanácsadáson vettek részt [36], egy speciálisan abortuszban érintett férfiak számára kidolgozott, megbocsátásfókuszú terápiás program pedig hatékonynak mutatkozott a düh, a szomorúság és a szorongás érzéseinek oldásában [37]. További jelentős eredmény, hogy a férfiak igényeihez igazított tájékoztatás jelentősen növeli a férfi partnerek elégedettségét az abortuszellátásra vonatkozóan, ami pedig pozitív hatással van a nők elégedettségére is [38], és ez mint a korábbiakban említettük - pozitívan befolyásolja a beavatkozás utáni pszichés felépülést [25]. A férfiak által nem megfelelőnek észlelt tanácsadás ugyanakkor az intruzív gondolatok és az elkerülés (mint a poszttraumás stressz tünetei), valamint az abortusz utáni párkapcsolati problémák nagyobb valószínúségével jár együtt [39].

A tanulmányok felhívják a figyelmet arra, hogy mivel általában is keveset tudunk a témáról, az abortuszellátásban a szolgáltatók oldaláról részt vevők egyrészt alábecsülik annak a támasznak a jelentőségét, amelyet férfi partnerek a nők számára nyújtanak [30], másrészt kevéssé felkészültek a férfi partnerek támogatására, ami tovább fokozza a jelen lévő férfiak kirekesztettségérzését [40, 41]. Bár a vizsgálati adatok alátámasztják, hogy az érintett férfiaknak van igényük a professzionális segítségre partnerük tervezett abortusza előtt vagy után, mégis nagyon kevés, speciálisan a férfi érintetteket célzó tanácsadási protokoll és intervenció került ez idáig kidolgozásra, és ezek hatékonysága sem igazolt. A nemzetközi

\footnotetext{
${ }^{1}$ Ezen eredmények természetesen nem kezelhetők függetlenül attól, hogy az adott társadalomban a férfiak általában véve milyen mértékben vesznek igénybe mentális egészségügyi szolgáltatásokat, az mennyire stigmatizáló, stb.
}

szakirodalomban 1977 és 2017 között mindössze két, a témát érintő intervenciós tanulmányt találtunk [36, 37]. Inkább az a helyzet jellemző, hogy a pár együtt megy tanácsadásra (pontosabban, a nő számára megajánlott tanácsadási helyzetben informálisan a férfi is részt vesz), ám ez - még ha a párkapcsolat szempontjából pozitív is - az igények és szükségletek különbözősége miatt a férfi partner szempontjából nem minden esetben megfelelö vagy elégséges [39]. Problémát jelenthet a férfiak motiválása is, de ez részben az adott kultúra befolyása alatt áll (például a segítségkérés mennyire egyeztethető össze a férfiszereppel), másrészt immanensen függ össze azzal, hogy akár a társadalmi diskurzus, akár az egészségügyi ellátás szintjén mennyiben tematizálódik az abortusz kizárólag női kérdésként [39].

\section{A fogantatásért vállalt közös felelősség}

A statisztikai adatok szerint a nem kívánt várandósságok csaknem fele végződik múvi abortusszal [42], így a terhességmegszakítások számának mérséklésére az egyik megoldás lehet a (hatékonyabb) fogamzásgátló eszközök használata és ezáltal a nem kívánt terhességek számának csökkentése. A már említett Kairói Népesedési Világkonferencia kiemelt kutatási területként határozta meg a közös felelősségnek és a férfiak aktív részvételének kérdését a szexuális és reproduktív egészségügyben, valamint a családtervezésben („partners in reproduction”). Ennek hatására az egészségpolitikákban, a társadalom különböző rétegeit megszólító kampányokban és a tudományos kutatások terén is mind nagyobb hangsúlyt kapott a férfiak felelősségvállalásának ösztönzése az apaság (és a gyermeknevelés), de ugyanígy a terhességmegelőzés terén is [15]. A közös felelősség hangsúlyozása már csak azért is központi a múvi terhességmegszakítás kapcsán, mert a modern és széles körben hozzáférhető fogamzásgátló módszerek elterjedésével a nem kívánt várandósság önmagában is a felelősségteljes (szexuális) viselkedés hiányaként tételeződik. Így az, hogy a férfi partner milyen mértékben vesz részt a terhesség megtartására/ megszakítására vonatkozó döntésben, valószínűsíthetően összefügg azzal is, hogy magáért a fogantatásért (illetve elkerülése kudarcáért) mennyire vállalja a felelősséget. Ha a fogamzásgátlás a partnerek közös felelössége, akkor feltételezhető, hogy a döntés a nem kívánt terhességról is az lesz - bár ez az összefüggés még további tudományos igazolásra vár [43].

Az elégtelen védekezés és a múvi vetélés összefüggését alátámasztják azok a hazai adatok is, amelyek szerint a terhességük megszakítását kérő nők többségénél a várandósság a fogamzásgátlás hiánya miatt jöhet létre: a nők kevesebb mint fele védekezett rendszeresen a nem kívánt fogantatás előtt, és köztük is nagy arányban szerepeltek a természetes védekezést vagy más, kevéssé hatékony módszereket alkalmazók [44]. Számos kutatás igazolja, hogy a fogamzásgátlás hatékonysága javítható az egyéni igényekhez igazított tanácsadással, akár többszöri abor- 
tuszon átesett nőknél is [45]. Ez részben a helytálló ismeretek növekedését, másrészt a hatékony védekezési módszerek választását és alkalmazásuk rendszeressé tételét jelenti. A tájékoztatás hatása fokozható akkor, ha nemcsak a nő, hanem a partnere is jelen van a konzultáción, vagyis a férfiak bevonása az abortuszellátásba e téren hasznos hozzájárulás lehet a múvi terhességmegszakítások számának csökkentéséhez [46, 47].

\section{Következtetések}

Ahogy a társadalom szintjén nem gondolkodhatunk az egészségi állapotról anélkül, hogy az ellátásra vonatkozó paramétereket ne vennénk számításba, úgy a múvi terhességmegszakítást, annak gyakoriságát, számát, egyéb mutatóit sem érdemes az ellátási oldaltól függetlenül kezelni. Bár relatíve kevés kutatási adat áll még rendelkezésünkre, azok eredményei egy irányba mutatnak: az abortuszellátáson belül szükséges a pszichés tényezők fontosságát is szem előtt tartani és ezzel összefüggésben nagyobb figyelmet fordítani az ellátás során a férfi partnerek szerepére. Ez jelenti részben fokozottabb bevonásukat az ellátás folyamatába, másrészt igényeikhez, elvárásaikhoz igazított információátadási, tanácsadási és intervenciós gyakorlatok kidolgozását és azok hatékonyságának ellenőrzését.

Sz. Makó [48] szerint a múvi abortuszt megelőző időszakban a pszichoszociális intervenciók fontos területét képezi a) a terhesség kimenetelével kapcsolatos helyzetelemzés és döntéshozatal támogatása, b) a krízisintervenció, c) súlyos kapcsolati problémák esetén a partnerek közti problémamegoldás segítése, d) az eseménnyel való megküzdéshez az erőforrások mobilizálása, e) a mütétre történő pszichológiai felkészítés, f) a tájékoztatás az abortusz utáni pszichés reakciókról és a komplikált feldolgozás jegyeiről, g) a pszichés problémák szempontjából magas rizikójú csoportba tartozók kiszűrése és h) az ismétlődő múvi abortuszok elkerülését célzó intervenciók. Mindezek azonban, amint azt a fentiekben bemutatott szakirodalmi adatok is alátámasztják, nemcsak a nők, hanem a múvi abortuszban érintett férfiak vonatkozásában is fontosak lennének. Mindennek segítségével emelkedne a partnerek informáltsága, amely a megfelelően mérlegelt döntés és egyben a döntésért vállalt felelősség alapja is. A nők nagyjából harmada ambivalens a beavatkozás elvégzése előtt, jelentős részük az aktuálisan elvetetni tervezett várandósság előtt a terhesség kihordását választotta volna, és más döntésre jutna, ha a körülményei változnának, például ha a partner másként állna a gyermekvállalás kérdéséhez [49]. A kifejezetten férfiakat célzó információátadás és intervenciók segítségével emelkedhetne a két fél egyetértésével meghozott, közös döntések aránya - akár a terhesség megtartására irányuló döntéseké is. Hazánkban az összes müvi vetélés mintegy egyharmadát olyan nőkön végzik, akiknek korábban volt már legalább egy terhességmegszakításuk [44]. A többszörös abortuszok számának csökkentése a fogamzásgát- lási szokások megváltoztatása nélkül nem képzelhető el, ebben pedig a férfi partnereknek is szerepük és felelősségük van. Célzott informálásuk tehát ebból a szempontból is segítené az elvetetett várandósságok számának visszaszorítását. Másfelől, ha a várandósság megszüntetésében részes férfiak, az ő érzéseik, gondolataik, motivációik és szükségleteik láthatatlanok maradnak, az egyéni szinten (illetve a párok vonatkozásában) negatív hatással járhat a döntéssel és annak következményeivel való megküzdésre, társadalmi szinten pedig gátja lehet a művi abortuszok számának csökkenését célzó programok eredményességének.

Anyagi támogatás: A közlemény megírása, illetve a kapcsolódó kutatómunka anyagi támogatásban nem részesült.

Szerzôi munkamegosztás: N. B. M.: Adatgyüjtés, a közlemény megírása. R. A.: A közlemény javítása, kiegészítése, végleges korrektúra. A cikk végleges változatát mindkét szerző elolvasta és jóváhagyta.

Érdekeltségek: A szerzőknek nincsenek érdekeltségeik.

\section{Irodalom}

[1] Hungarian Central Statistical Office. Hungary, 2017. [Központi Statisztikai Hivatal. Magyarország, 2017.] Available from: http://www.ksh.hu/docs/hun/xftp/idoszaki/mo/mo2017. pdf [accessed: November 7, 2018]. [Hungarian]

[2] Johnston's Archive. Abortion worldwide report. Available from: http://www.johnstonsarchive.net/policy/abortion/wrjp336pd.html [accessed: Szeptember 27, 2018].

[3] Jones RK, Moore AM, Frohwirth LF. Perceptions of male knowledge and support among U.S. women obtaining abortions. Womens Health Issues 2011; 21: 117-123.

[4] Major B, Zubek JM, Cooper ML, et al. Mixed messages: implications of social conflict and social support within close relationships for adjustment to a stressful life event. J Pers Soc Psychol. 1997; 72: 1349-1363.

[5] Turay A, Horváth B, Kovács L, et al. Induced abortion and relationships. [Terhességmegszakítás és párkapcsolat.] Magy Nőorv L. 1997; 60: 227-230. [Hungarian]

[6] World Health Organization. Safe abortion: technical and policy guidance for health systems. WHO, Geneva, 2012. Available from: apps.who.int/iris/bitstream/10665/70914/1/ 9789241548434_eng.pdf [accessed: May 21, 2018].

[7] National Abortion Federation. 2018 Clinical Policy Guidelines for Abortion Care. Washington, DC, 2018. Available from: https://5aalb2xfmfh2e2mk03kk8rsx-wpengine.netdna-ssl. com/ wp-content/uploads/2018_CPGs.pdf [accessed: July 12, 2018].

[8] Kimport K, Foster K, Weitz TA. Social sources of women's emotional difficulty after abortion: lessons from women's abortion narratives. Perspect Sex Reprod Health 2011; 43: 103-109.

[9] American Psychological Association. Report of the Task Force on Mental Health and Abortion. Washington, DC, 2008. Available from: http://www.apa.org/pi/wpo/mental-health-abortion-report.pdf [accessed: May 21, 2018].

[10] Foster DG, Jackson RA, Cosby K, et al. Predictors of delay in each step leading to an abortion. Contraception 2008; 77 : 289293.

[11] Kapadia F, Finer LB, Klukas E. Associations between perceived partner support and relationship dynamics with timing of preg- 
nancy termination. Womens Health Issues 2011; 21(3 Suppl): S8-S13.

[12] Bartlett LA, Berg CJ, Shulman HB, et al. Risk factors for legal induced abortion-related mortality in the United States. Obstet Gynecol. 2004; 103: 729-737.

[13] Vandamme J, Buysse A, Loeys T, et al. The decision to have an abortion from both partners' perspectives: a dyadic analysis. Eur J Contracept Reprod Health Care 2017; 22: 30-37.

[14] Richardson CT, Nash E. Misinformed consent: the medical accuracy of state-developed abortion counseling materials. Guttmacher Policy Review 2006; 9: 6-11

[15] Reich JA, Brindis CD. Conceiving risk and responsibility: a qualitative examination of men's experiences of unintended pregnancy and abortion. Int J Mens Health 2006; 5: 133-152.

[16] Altshuler AL, Nguyen BT, Riley HE, et al. Male partners' involvement in abortion care: a mixed methods systematic review. Perspect Sex Reprod Health 2016; 48: 209-219.

[17] Becker S, Bazant ES, Meyers C. Couples counseling at an abortion clinic: a pilot study. Contraception 2008; 78: 424-431.

[18] Major B, Mueller P, Hildebrandt K. Attributions, expectations, and coping with abortion. J Pers Soc Psychol. 1985; 48: 585599

[19] Major B, Cozzarelli C, Sciacchitano AM, et al. Perceived social support, self-efficacy, and adjustment to abortion. J Pers Soc Psychol. 1990; 59: 452-463.

[20] Cozzarelli C, Karrasch A, Sümer N, et al. The meaning and impact of partner's accompaniment on women's adjustment to abortion. J Appl Soc Psychol. 1994; 24: 2028-2056.

[21] Guilbert E, Roter D. Assessment of satisfaction with induced abortion procedure. J Psychol. 1997; 131: 157-166.

[22] Makenzius M, Tydén T, Darj E, et al. Women and men's satisfaction with care related to induced abortion. Eur J Contracept Reprod Health Care 2012; 17: 260-269.

[23] Abdel-Aziz E, Hassan IM, Al-Taher H. Assessment of women's satisfaction with medical termination of pregnancy. J Obstet Gynaecol. 2004; 24: 429-433

[24] Kopp Kallner H, Fiala, C, Gemzell-Danielsson K. Assessment of significant factors affecting acceptability of home administration of misoprostol for medical abortion. Contraception 2012; 85: 394-397.

[25] Wallin Lundell I, Öhman SG, Sundström Poromaa I, et al. How women perceive abortion care: a study focusing on healthy women and those with mental and posttraumatic stress. Eur J Contracept Reprod Health Care 2015; 20: 211-222.

[26] Kero A, Lalos A, Wulff M. Home abortion - experiences of male involvement. Eur J Contracept Reprod Health Care 2010; 15: 264-270.

[27] Kero A, Wulff M, Lalos A. Home abortion implies radical changes for women. Eur J Contracept Reprod Health Care 2009; 14: 324-333

[28] Bracken MB, Hachamovitch M, Grossman G. The decision to abort and psychological sequelae. J Nerv Ment Dis. 1974; 158: 154-162.

[29] Shusterman LR. Predicting the psychological consequences of abortion. Soc Sci Med. Med Psychol Med Sociol. 1979; 13A: 683-689

[30] Veiga MB, Lam M, Gemeinhardt C, et al. Social support in the post-abortion recovery room: evidence from patients, support persons and nurses in a Vancouver clinic. Contraception 2011; 83: $268-273$

[31] Abdel-Tawab N, Huntington D, Hassan EO, et al. Effects of husband involvement on postabortion patients' recovery and use of contraception in Egypt. In: Huntington D, Piet-Pelon NJ. (eds.) Postabortion care: lessons from operational research. Population Council, New York, NY, 1999; pp. 16-37.
[32] Elul B, Pearlman E, Sorhaindo A, et al. In-depth interviews with medical abortion clients: thoughts on the method and home administration of misoprostol. J Am Med Womens Assoc. 2000; 55(3 Suppl): 169-172.

[33] Lauzon P, Roger-Achim D, Achim A, et al. Emotional distress among couples involved in first-trimester induced abortions. Can Fam Physician 2000; 46: 2033-2040.

[34] Papworth V. Abortion services: the need to include men in care provision. Nurs Stand. 2011; 25: 35-37.

[35] Shostak A. Men, me, and abortion: on doing the right thing. Men Masculinities 2008; 10: 360-366.

[36] Gordon RH. Efficacy of a group crisis-counseling program for men who accompany women seeking abortions. Am J Community Psychol. 1978; 6: 239-246.

[37] Coyle CT, Enright RD. Forgiveness intervention with postabortion men. J Consult Clin Psychol. 1997; 65: 1042-1046.

[38] Makenzius, M. Unintended pregnancy, abortion and prevention. Women and men's experiences and needs. Doctoral dissertation. Acta Universitatis Upsaliensis, Uppsala, 2012. Available from: http://citeseerx.ist.psu.edu/viewdoc/download?doi=10.1.1.8 59.1627\&rep=rep 1 \& type=pdf [accessed: September 27, 2018]

[39] Coyle CT, Coleman PK, Rue VM. Inadequate preabortion coun seling and decision conflict as predictors of subsequent relationship difficulties and psychological stress in men and women. Traumatology 2010; 16: 16-30.

[40] Kero A, Lalos A. Reactions and reflections in men, 4 and 12 months post-abortion. J Psychosom Obstet Gynaecol. 2004; 25: 135-143.

[41] Halldén BM, Christensson K. Swedish young men's lived experiences of a girlfriend's early induced abortion. Int J Mens Health 2010; 9: 126-143

[42] Kågesten A, Bajos N, Bohet A, et al. Male experiences of unin tended pregnancy: characteristics and prevalence. Hum Reprod. 2015; 30: 186-196.

[43] Costescu DJ, Lamont JA. Understanding the pregnancy decision-making process among couples seeking induced abortion. J Obstet Gynaecol Can. 2013; 35: 899-904.

[44] Hungarian Central Statistical Office. Demographic characteristics of induced abortions. [Központi Statisztikai Hivatal. Terhességmegszakítások demográfiai jellemzői.] Available from: https://www.ksh.hu/docs/hun/xftp/stattukor/terhessegmegszll.pdf [accessed: September 27, 2018]. [Hungarian]

[45] Loeber OE, Muntinga ME. Contraceptive counselling for women with multiple unintended pregnancies: the abortion client's perspective. Eur J Contracept Reprod Health Care 2017; 22: 94-101.

[46] Zhu JL, Zhang WH, Cheng Y, et al. Impact of post-abortion family planning services on contraceptive use and abortion rate among young women in China: a cluster randomised trial. Eur J Contracept Reprod Health Care 2009; 14: 46-54.

[47] Stewart H, McCall SJ, McPherson C, et al. Effectiveness of periabortion counselling in preventing subsequent unplanned pregnancy: a systematic review of randomised controlled trials. J Fam Plann Reprod Health Care 2016; 42: 59-67.

[48] Sz. Makó H. Psychological perspectives of abortion care - when, what and how can psychotherapeutic assistance help during pregnancy termination. [Az „abortusz-ellátás” pszichológiai perspektívái - mikor, miben és hogyan segíthet a pszichoterápiás szemléletű szakellátás a terhesség-megszakítás során.] Psychiat Hung. 2014; 29: 418-425. [Hungarian]

[49] Husfeldt C, Hansen SK, Lyngberg A, et al. Ambivalence among women applying for abortion. Acta Obstet Gynecol Scand. 1995; 74: 813-817.

(Nagy Beáta Magda, Szombathely, Dolgozók útja 1/A, 9700 e-mail: nagybeatamagda@imap.cc) 